\title{
ANALISIS PENGGUNAAN FORWARD CONTRACT DAN OPTION PADA PERUSAHAAN EKSPOR UD DAMENA DI DENPASAR
}

\author{
Gita Syeba Lubis ${ }^{1}$ \\ Henny Rahyuda ${ }^{2}$ \\ ${ }^{1,2}$ Fakultas Ekonomi dan Bisnis Universitas Udayana (Unud), Bali -Indonesia \\ e-mail: syebagita@gmail.com
}

\begin{abstract}
ABSTRAK
Perusahaan ekspor menerima penghasilan dalam mata uang asing sehingga akan terkena dampak dari adanya risiko exchange rate. Tujuan penelitian ini untuk mengetahui penerapan metode hedging forward contract dan option pada UD Damena (Seafood Supply \& Processing Product) tahun 2014-2016. Penelitian ini merupakan penelitian deskriptif kuantitatif. Objek penelitian yang digunakan adalah keuntungan selisih kurs dari penerimaan piutang transaksi ekspor yang diperoleh UD Damena (Seafood Supply \& Processing Product) pada tahun 2014-2016. Metode pengumpulan data yaitu observasi non perilaku dengan mengumpulkan data dari sumber tertulis dan metode wawancara untuk mengumpulkan profil perusahaan. Teknik analisis data menggunakan teknik deskriptif dengan menguraikan tahapan forward contract dan option secara sistematis. Hasil penelitian menyimpulkan bahwa forward contract dan option mampu meminimalisasi risiko exchange rate dengan menghasilkan selisih kurs yang lebih besar dan option menghasilkan peningkatan selisih kurs yang lebih besar daripada forward contract.
\end{abstract}

Kata kunci: risiko exchange rate, hedging, forward contract, option.

\begin{abstract}
The export company receives income in foreign currency so it will be affected by the exchange rate risk. The purpose of this research is to know the application of hedging forward contract and option method in UD Damena (Seafood Supply \& Processing Product) in 2014-2016. This research is quantitative descriptive. The research object is foreign exchange gain from export transaction receivables obtained by UD Damena (Seafood Supply \& Processing Product) in the period 2014-2016. Data collection methods are non-behavioral observation by collecting data from written sources and interview methods to collect company profiles. Data analysis techniques using descriptive techniques by describing the phases of forward contract and option systematically. The results concluded that forward contract and option minimize the risk of exchange rate by generating greater exchange rate difference and option resulted in a lager exchange rate increase than the forward contract.
\end{abstract}

Keyword: exchange rate risk, hedging, forward contract, option. 


\section{PENDAHULUAN}

Perkembangan era globalisasi menyebabkan lingkup bisnis semakin meluas hingga pada perdagangan internasional. Hal ini membuat setiap negara semakin meningkatkan produksi barang maupun jasa untuk dipasarkan hingga pasar internasional. Pangsa pasar yang semakin luas ini menciptakan suatu keuntungan bagi setiap perusahaan dengan ikut dalam transaksi perdagangan internasional dan memperoleh keuntungan yang sulit diperoleh apabila hanya melakukan transaksi bisnis dalam negeri.

Perusahaan yang melakukan transaksi perdagangan internasional akan menghadapi masalah yang lebih rumit daripada ketika perusahaan hanya berurusan dengan pasar domestik (Winarto, 2008). Masalah utama yang selalu dihadapi oleh perusahaan pada perdagangan internasional adalah adanya risiko exchange rate.

Mata uang yang selalu berfluktuasi menjadi sebuah risiko yang harus dikelola oleh perusahaan. Risiko ini dapat memengaruhi operasional perusahaan dengan dampak yang diberikan berupa penurunan pendapatan atau peningkatan biaya yang ditanggung perusahaan.

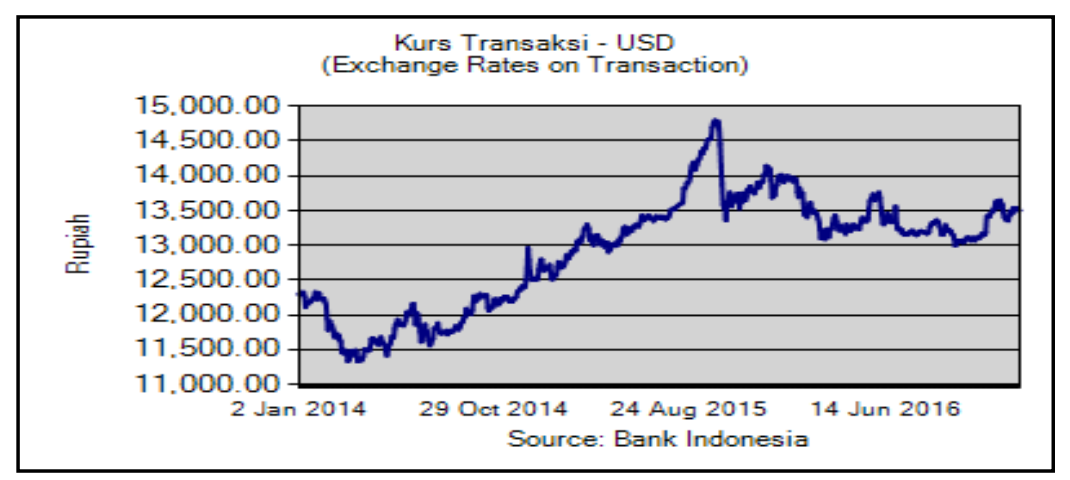

Gambar 1. Kurs Transaksi USD Tahun 2014-2016

Sumber: www.bi.go.id 
Gita Syeba Lubis, Analisis Penggunaan Forward Contract dan Option...

Gambar 1 menunjukkan grafik fluktuasi mata uang Rupiah terhadap US Dollar pada Tahun 2014-2016. Pada Tahun 2014 terjadi fluktuasi mata uang Rupiah terhadap US Dollar yang diawali dengan apresiasi kemudian berganti menjadi cenderung mengalami depresiasi. Ketika memasuki Tahun 2015, People's Bank of China/PBOC (Bank Sentral China) mengumumkan isu akan terjadi devaluasi Yuan yang dilakukan dengan tujuan untuk membuat mata uang Yuan menjadi salah satu mata uang yang berlaku secara internasional dan meningkatkan kinerja ekspor. Isu ini menyebabkan adanya pergerakan kurs serentak di seluruh dunia yang berfluktuasi untuk mengantisipasi keputusan yang diambil oleh pemerintah China. Pada saat terjadi devaluasi Yuan, nilai kurs US Dollar mengalami apresiasi sebesar $2 \%$ dan merupakan level terendah dalam 3 tahun periode. Hal ini memicu kurs Rupiah mengalami depresiasi yang cukup tinggi dan menyebabkan pelemahan Rupiah ke level terendah dalam 17 tahun terakhir.

Memasuki Tahun 2016, Bank Indonesia berhasil mengembalikan nilai kurs Rupiah ke posisi menguat. Pada pertengahan Tahun 2016 terjadi isu politik yang disebabkan oleh terpilihnya Presiden baru Amerika Serikat sehingga menyebabkan nilai Rupiah kembali mengalami depresiasi terhadap US Dollar. Namun, nilai kurs Rupiah kembali mengalami apresiasi dan membuat posisi Rupiah kembali menguat hingga di pengujung Tahun 2016 posisi Rupiah mengalami depresiasi. Fluktuasi mata uang yang terjadi akibat adanya keadaan ekonomi dan politik internasional yang tidak stabil 
dapat menyebabkan perusahaan ekspor menanggung risiko exchange rate yang lebih besar.

Pada awal bulan Januari 2014 hingga pertengahan Maret 2014 terjadi apresiasi Rupiah terhadap Dollar senilai Rp12.328 menjadi Rp11.370. Apresiasi Rupiah juga terjadi pada akhir bulan September 2015 hingga pertengahan Oktober 2015 senilai Rp14.802 menjadi Rp13.354. Hal ini menunjukkan adanya risiko yang dihadapi oleh perusahaan ekspor yang dapat menyebabkan pendapatan atas transaksi ekspor mengalami penurunan. Sedangkan pada akhir bulan Juli 2015 hingga akhir September 2015 terjadi depresiasi Rupiah terhadap Dollar senilai Rp13.435 menjadi Rp14.802. Hal ini menjadi sebuah keuntungan bagi perusahaan ekspor karena jumlah pendapatan atas transaksi ekspor yang diterima mengalami peningkatan.

Untuk mengatasi risiko exchange rate perusahaan dapat menggunakan metode hedging yaitu dengan melindungi nilai suatu mata uang tertentu di masa depan. Hedging dengan instrumen derivatif dapat dilakukan dengan menggunakan teknik forward contract, option, futures, currency swap, dan money market hedging. Pada penelitian ini teknik hedging yang digunakan adalah forward contract dan option karena kedua teknik ini memiliki perbedaan sifat dimana forward contract merupakan hak dan kewajiban untuk dilakukan sedangkan option merupakan sebuah hak namun bukan kewajiban. 
Gita Syeba Lubis, Analisis Penggunaan Forward Contract dan Option...

Penelitian ini menggunakan objek berupa hasil penggunaan forward contract dan option yang dilihat dari peningkatan selisih kurs dari piutang transaksi ekspor yang diperoleh UD Damena (Seafood Supply \& Processing Product) pada Tahun 2014-2016. Setiap transaksi yang dilakukan oleh UD Damena menggunakan mata uang US Dollar. Perusahaan yang beralamat di Jalan Mina Utama 8X By Pass Ngurah Rai, Denpasar, Bali ini telah berbisnis sejak tahun 2000. Sejak awal didirikan hingga saat ini, UD Damena tidak pernah menerapkan hedging dalam transaksi bisnisnya sehingga penerimaan piutang perusahaan selalu terkena dampak dari adanya risiko exchange rate.

Berdasarkan uraian latar belakang yang telah dipaparkan sebelumnya, maka rumusan masalah dalam penelitian ini adalah: 1) Apakah forward contract dan option mampu meminimalisasi risiko exchange rate pada UD Damena pada Tahun 2014-2016? 2) Teknik hedging manakah antara forward contract dan option yang lebih baik digunakan dalam meminimalisasi risiko exchange rate pada UD Damena pada Tahun 20142016? Berdasarkan rumusan masalah yang telah diuraikan sebelumnya, maka tujuan dari penelitian ini adalah: 1) Untuk mengetahui penerapan forward contract dan option dalam meminimalisasi risiko exchange rate pada UD Damena pada Tahun 2014-2016. 2) Untuk mengetahui penerapan teknik hedging antara forward contract dan option yang lebih baik dalam meminimalisasi risiko exchange rate pada UD Damena pada Tahun 20142016. 
Kegunaan teoritis yang diperoleh dari penelitian ini diharapkan dapat memberikan tambahan kajian empiris mengenai dampak penerapan hedging terutama dengan teknik hedging forward contract dan option pada perusahaan internasional dalam meminimalisasi risiko exchange rate dan memberikan bukti empiris mengenai teori yang telah ada dari hasil penelitian serta menjawab research gap pada penelitian terdahulu. Kegunaan praktis penelitian ini diharapkan mampu memberikan bahan pertimbangan bagi perusahaan ekspor dalam menerapkan hedging dengan instrumen derivatif khususnya teknik forward contract dan option sebagai upaya perlindungan dari risiko exchange rate serta dapat mengambil keputusan dalam memilih teknik hedging yang dapat menghasilkan peningkatan selisih kurs pada penerimaan piutang.

Perdagangan internasional merupakan pendekatan yang relatif konservatif yang dapat digunakan oleh perusahaan untuk menembus pasar (melalui ekspor) atau untuk memperoleh barang dengan biaya rendah (melalui impor) (Madura, 2006:12). Perdagangan internasional terjadi karena didorong oleh beberapa faktor seperti dorongan untuk memenuhi kebutuhan barang dan jasa dalam negeri, keinginan memperoleh keuntungan dan meningkatkan pendapatan negara, adanya perbedaan kemampuan penguasaan ilmu pengetahuan dan teknologi dalam mengolah sumber daya ekonomi, serta terjadinya era globalisasi sehingga tidak satu negara pun di dunia dapat hidup sendiri (Ball, 2004). Namun, dibalik segala manfaat yang bisa diperoleh pada perdagangan internasional juga terdapat risiko yang 
Gita Syeba Lubis, Analisis Penggunaan Forward Contract dan Option...

harus ditanggung oleh setiap perusahaan yang terlibat di dalamnya. Risiko tambahan yang paling nyata adalah adanya ketidakpastian kurs (Levi, 2001:6).

Risiko utama yang dihadapi oleh perusahaan yang berbisnis secara internasional adalah risiko exchange rate. Risiko exchange rate adalah perubahan nilai tukar atau kurs yang tidak pasti mengarah kepada fluktuasifluktuasi tidak pasti pada nilai perusahaan (Musthafa, 2017:222). Perubahan kurs yang tak terduga memiliki dampak penting pada penjualan, harga, dan laba eksportir dan importir (Levi, 2001:6). Penerapan sistem nilai tukar mengambang di Indonesia juga menambah besar risiko fluktuasi tersebut (Guniarti, 2014). Nilai tukar mengambang bebas merupakan sistem dimana pemerintah tidak mencampuri tingkat nilai tukar sama sekali sehingga nilai tukar diserahkan pada permintaan dan penawaran valuta asing (Schubert, 2011). Menurut Aryanti (2005) dan Moehrle (2005), untuk mengantisipasi pergerakan nilai tukar yang fluktuatif, perlu diterapkan manajemen lindungi nilai.

Hedging merupakan suatu tindakan melindungi perusahaan untuk menghindari atau mengurangi risiko kerugian atas valuta asing sebagai akibat dari terjadinya transaksi bisnis (Guniarti, 2014). Metode hedging dapat diterapkan dengan menggunakan beberapa teknik yaitu diantaranya forward contract, option, future contract, currency swap dan money market hedging. Derivatif merupakan kontrak perjanjian antara dua pihak untuk menjual dan membeli sejumlah barang (baik komoditas, maupun sekuritas) 
pada tanggal tertentu di masa yang akan datang dengan harga yang telah disepakati pada saat ini (Utomo, 2000).

Forward contract adalah perjanjian antara sebuah perusahaan dengan sebuah bank komersial untuk menukar sejumlah mata uang tertentu dengan kurs nilai tukar tertentu yang disebut kurs forward pada tanggal tertentu di masa depan (Madura, 2006:147). Forward contract akan menguntungkan apabila forward rate lebih besar dari spot rate di masa yang akan datang. Penelitian sebelumnya mengenai penerapan forward contract dalam meminimalisasi risiko exchange rate telah dilakukan oleh Rinny dan Saputra (2016) yang menyimpulkan bahwa penerapan forward contract yang dilakukan oleh PT TD Automotive Compressor Indonesia mengalami kerugian selisih kurs. Sedangkan hasil berbeda diperoleh pada penelitian Rofifah dkk. (2017) dan Alim (2014) yang menemukan hasil bahwa forward contract mampu melindungi perusahaan dari risiko exchange rate dan menghasilkan peningkatan selisih kurs.

Option adalah kontrak yang memberikan hak (bukan kewajiban) kepada pemegang kontrak itu untuk membeli (call options) atau menjual (put options) suatu aset tertentu dengan harga tertentu (strike price) dalam jangka waktu tertentu (Fahmi, 2016:415). Opsi beli suatu mata uang akan dikatakan menguntungkan (in the money) jika kurs nilai tukar saat ini lebih tinggi dari strike price (Madura, 2006:164). Opsi beli dapat digunakan untuk perlindungan dari kenaikan harga valuta atau harga komoditas yang akan digunakan pemegang opsi (Repie dan Sedana, 2014). Opsi jual mata 
Gita Syeba Lubis, Analisis Penggunaan Forward Contract dan Option...

uang dikatakan menguntungkan (in the money) jika kurs nilai tukar saat ini lebih kecil dari strike price (Madura, 2006:169). Opsi jual dapat digunakan sebagai sarana hedging untuk memproteksi penurunan nilai suatu valuta (Repie dan Sedana, 2014). Apabila pada saat jatuh tempo option mendatangkan keuntungan maka option dapat dilaksanakan, namun apabila yang terjadi adalah option tidak mendatangkan keuntungan maka option boleh untuk tidak dilaksanakan. Penelitian sebelumnya mengenai penerapan option dalam meminimalisasi risiko exchange rate telah dilakukan oleh Maurer dan Valiani (2007) yang meneliti tentang keefektifan pengendalian risiko mata uang terhadap international diversified mixed-asset portfolios dengan menggunakan forward contract dan currency option dan hasil penelitiannya menunjukkan bahwa option dan forward contract mampu meminimalisasi risiko exchange rate dan hasil penelitian menunjukkan bahwa put option memberikan keuntungan lebih besar daripada forward contract. Penelitian yang dilakukan oleh Chan et al. (2003) yang menganalisis penggunaan dua teknik hedging yaitu forward contract dan pasar opsi untuk menghadapi eksposur transaksi pada eksportir. Hasil penelitian menyimpulkan bahwa penerapan kontrak forward lebih efektif daripada pasar opsi pada saat Asian Crisis 1997 sedangkan pasar opsi lebih efektif daripada kontrak forward pada saat dan sesudah Asian Crisis 1997. Penelitian yang dilakukan oleh Khazeh dan Winder (2006) mengenai penerapan money market hedging dan option pada utang dan piutang yang dimiliki oleh perusahaan multinasional menunjukkan hasil metode money 
market hedging lebih menguntungkan digunakan pada utang dan piutang dalam bentuk mata uang Poundsteling Inggris dan Marks Jerman sedangkan metode hedging option lebih menguntungkan digunakan pada piutang perusahaan dalam bentuk mata uang Yen Jepang dan Francs Swiss.

\section{METODE PENELITIAN}

Penelitian ini dilakukan pada perusahaan ekspor UD Damena (Seafood Supply \& Processing Product) Tahun 2014-1016. Jenis data yang digunakan dalam penelitian ini terdiri dari data kuantitatif. Sumber data yang digunakan dalam penelitian ini adalah data sekunder berupa data piutang ekspor UD Damena (Seafood Supply \& Processing Product) per bulan, kurs spot per transaksi, suku bunga deposito US Dollar per tahun, suku bunga deposito Rupiah Indonesia per tahun, dan jangka waktu jatuh tempo piutang per transaksi selama periode 2014-2016.

Penelitian ini dilakukan untuk mengetahui penggunaan forward contract dan option pada perusahaan ekspor UD Damena Tahun 2014-1016 sehingga terdapat dua variabel dalam penelitian ini yaitu forward contract dan option. Forward contract dilakukan oleh pihak perusahaan dengan bank komersial untuk menyepakati nilai suatu mata uang di masa depan yang ditetapkan pada saat ini. Analisis forward contract dilakukan dengan rumus:

$$
\text { Spot rate }+\frac{(\text { interest rate differential } \times \text { spot rate } x \text { days })}{360 \times 100}
$$

Keterangan:

Forward rate $\quad=$ kurs transaksi yang ditetapkan pada kontrak 
Gita Syeba Lubis, Analisis Penggunaan Forward Contract dan Option...

$\begin{array}{ll}\text { Spot rate } & =\text { kurs yang berlaku saat jatuh tempo kontrak } \\ \text { Interest rate differential } & =\text { selisih suku bunga deposito mata uang negara } \\ & \begin{array}{l}\text { domestik dengan suku bunga deposito mata uang } \\ \text { negara asing }\end{array} \\ & =\text { jangka waktu jatuh tempo pada kontrak }\end{array}$

Setelah forward rate diketahui, langkah selanjutnya adalah menghitung jumlah penerimaan piutang transaksi ekspor apabila menggunakan forward contract. Perhitungan dilakukan dengan menggunakan rumus:

Piutang transaksi ekspor $=$ Nilai transaksi ekspor $\mathrm{x}$ forward rate

Perbedaan nilai kurs spot dan forward rate menjadi penentu apakah forward contract memberikan mampu meminimalisasi risiko exchange rate. Perbedaan nilai yang terjadi dapat berupa forward discount atau premium yang ditetapkan dalam bentuk persentase. Perhitungan forward premium/discount dilakukan dengan menggunakan rumus:

$$
\text { Forward premium/discount }=\left(\frac{\mathrm{F}}{\mathrm{S}}-1\right) \times\left(\frac{360}{\text { days }}\right)
$$

Keterangan:

$\mathrm{F}=$ Forward rate

$\mathrm{S}=$ Spot rate

Option dilakukan oleh pihak pembeli dan penjual dengan menetapkan nilai suatu mata uang di masa depan (strike price) pada waktu saat ini 
dengan membayar biaya premi di muka. Analisis option dilakukan dengan rumus:

(5\% x Kurs spot tiap awal bulan) + Kurs Spot Transaksi

Setelah menentukan nilai strike price, selanjutnya adalah menentukan biaya premi yang harus dibayarkan perusahaan untuk menyepakati kontrak. Premi opsi jual (P) memiliki batas bawah nol atau selisih antara strike price (X) dan kurs spot nilai tukar terkait (S), tergantung dari mana yang lebih tinggi (Madura, 2009:194).

$$
\mathrm{P}=\operatorname{MAX}(0, \mathrm{X}-\mathrm{S})
$$

Keterangan:

$\mathrm{P}=$ Premi per unit put option

$\mathrm{X}=$ Strike Price

$\mathrm{S}=$ Kurs Spot

Pada penelitian ini tidak terdapat populasi dan sampel karena merupakan suatu studi kasus pada UD Damena. Studi kasus ini untuk mengetahui penggunaan forward contract dan option dalam meminimalisasi risiko exchange rate pada perusahaan ekspor UD Damena Tahun 20142016.

Metode pengumpulan data yang digunakan pada penelitian ini berupa observasi non perilaku. Metode observasi non perilaku dilakukan dengan cara mengumpulkan data piutang ekspor perusahaan UD Damena per bulan, kurs spot per transaksi, suku bunga deposito US Dollar per tahun, suku 
Gita Syeba Lubis, Analisis Penggunaan Forward Contract dan Option...

bunga deposito Rupiah Indonesia per tahun, dan jangka waktu jatuh tempo piutang per transaksi selama periode 2014-2016 dari sumber tertulis.

Teknik analisis data pada penelitian ini adalah teknik analisis deskriptif yang menguraikan tahapan forward contract dan option secara sistematis. Tahapan tersebut dilakukan dengan cara yaitu pertama, menghitung selisih kurs dengan menggunakan forward contract hedging, kedua menghitung selisih kurs dengan menggunakan option, ketiga membandingkan hasil keuntungan pada perusahaan UD Damena apabila diasumsikan menggunakan forward contract, keempat membandingkan hasil keuntungan pada perusahaan UD Damena apabila diasumsikan menggunakan option, dan terakhir mengambil kesimpulan dari data yang telah diolah dan dianalisis.

\section{HASIL DAN PEMBAHASAN}

Teknik forward contract hedging dilakukan oleh perusahaan dengan pihak bank dengan menentukan kesepakatan harga kurs (forward rate) yang kemudian ditetapkan pada kontrak. Perusahaan tidak pernah menerapkan teknik forward contract hedging, maka diasumsikan jangka waktu jatuh tempo forward contract hedging adalah 30 hari. Berikut merupakan tabel hasil analisis jumlah penerimaan piutang dengan menggunakan teknik forward contract hedging. 
Tabel 1.

Tabel Analisis Teknik Forward Contract Hedging Tahun 2014

\begin{tabular}{|c|c|c|c|c|c|c|c|c|c|c|}
\hline No & $\begin{array}{c}\text { Tanggal } \\
\text { Transaksi }\end{array}$ & $\begin{array}{l}\text { Kurs } \\
\text { Spot } \\
\text { (Rp) }\end{array}$ & $\begin{array}{c}\text { Nilai } \\
\text { Transaksi } \\
\text { (USD) }\end{array}$ & $\begin{array}{c}\text { Bunga } \\
\text { Deposito } \\
\text { Per } \\
\text { Tahun } \\
\text { (\%) } \\
\text { USD }\end{array}$ & $\begin{array}{c}\text { Bunga } \\
\text { Deposi } \\
\text { to Per } \\
\text { Tahun } \\
(\%) \\
\text { Rp }\end{array}$ & $\begin{array}{c}\text { Selisih } \\
(\%)\end{array}$ & $\begin{array}{c}\text { Jatuh } \\
\text { Tempo } \\
\text { Forward } \\
\text { Contract } \\
\text { (Hari) }\end{array}$ & $\begin{array}{c}\text { Forward } \\
\text { Premium } \\
\quad(\%)\end{array}$ & $\begin{array}{c}\text { Kurs } \\
\text { Forward } \\
\text { (Rp) }\end{array}$ & $\begin{array}{c}\text { Jumlah Piutang } \\
\text { Usaha (Rp) }\end{array}$ \\
\hline 1 & 03-01-14 & 12287 & 8625.24 & 2.34 & 9.04 & 6.7 & 30 & 6.70 & 12355.60 & 106570036.19 \\
\hline 2 & $13-01-14$ & 12107 & 6546.70 & 2.34 & 9.04 & 6.7 & 30 & 6.70 & 12174.60 & 79703436.91 \\
\hline 3 & 27-01-14 & 12259 & 2199.15 & 2.34 & 9.04 & 6.7 & 30 & 6.70 & 12327.45 & 27109903.05 \\
\hline 4 & 02-04-14 & 11360 & 5645.98 & 2.34 & 9.04 & 6.7 & 30 & 6.70 & 11423.43 & 64496438.49 \\
\hline 5 & 08-04-14 & 11366 & 5909.90 & 2.34 & 9.04 & 6.7 & 30 & 6.70 & 11429.46 & 67546966.64 \\
\hline 6 & $14-04-14$ & 11501 & 4369.12 & 2.34 & 9.04 & 6.7 & 30 & 6.70 & 11565.21 & 50529807.43 \\
\hline 7 & $25-04-14$ & 11659 & 6605.39 & 2.34 & 9.04 & 6.7 & 30 & 6.70 & 11724.10 & 77442227.03 \\
\hline 8 & 06-05-14 & 11569 & 4591.05 & 2.34 & 9.04 & 6.7 & 30 & 6.70 & 11633.59 & 53410409.82 \\
\hline 9 & $02-06-14$ & 11799 & 4172.04 & 2.34 & 9.04 & 6.7 & 30 & 6.70 & 11864.88 & 49500744.57 \\
\hline 10 & $18-06-14$ & 12038 & 3695.56 & 2.34 & 9.04 & 6.7 & 30 & 6.70 & 12105.21 & 44735537.87 \\
\hline 11 & $10-07-14$ & 11607 & 4875.78 & 2.34 & 9.04 & 6.7 & 30 & 6.70 & 11671.81 & 56909157.04 \\
\hline 12 & 02-09-14 & 11793 & 4467.00 & 2.34 & 9.04 & 6.7 & 30 & 6.70 & 11858.84 & 52973457.26 \\
\hline 13 & $24-09-14$ & 12036 & 4357.27 & 2.34 & 9.04 & 6.7 & 30 & 6.70 & 12103.20 & 52736914.62 \\
\hline 14 & 03-10-14 & 12205 & 7420.60 & 2.34 & 9.04 & 6.7 & 30 & 6.70 & 12273.14 & 91074096.70 \\
\hline 15 & $16-10-14$ & 12268 & 3052.41 & 2.34 & 9.04 & 6.7 & 30 & 6.70 & 12336.50 & 37656044.77 \\
\hline 16 & $29-10-14$ & 12224 & 5919.05 & 2.34 & 9.04 & 6.7 & 30 & 6.70 & 12292.25 & 72758446.31 \\
\hline 17 & 03-11-14 & 12166 & 5279.68 & 2.34 & 9.04 & 6.7 & 30 & 6.70 & 12233.93 & 64591218.82 \\
\hline 18 & $13-11-14$ & 12252 & 3150.41 & 2.34 & 9.04 & 6.7 & 30 & 6.70 & 12320.41 & 38814333.42 \\
\hline 19 & $17-11-14$ & 12254 & 5969.94 & 2.34 & 9.04 & 6.7 & 30 & 6.70 & 12322.42 & 73564097.11 \\
\hline 20 & 09-12-14 & 12409 & 4304.86 & 2.34 & 9.04 & 6.7 & 30 & 6.70 & 12478.28 & 53717263.87 \\
\hline 21 & $10-12-14$ & 12398 & 6697.93 & 2.34 & 9.04 & 6.7 & 30 & 6.70 & 12467.22 & 83504581.37 \\
\hline 22 & $12-12-14$ & 12494 & 1868.75 & 2.34 & 9.04 & 6.7 & 30 & 6.70 & 12563.76 & 23478523.07 \\
\hline \multicolumn{10}{|c|}{ Jumlah } & $1,322,823,642.36$ \\
\hline
\end{tabular}


Tabel 2.

Tabel Analisis Teknik Forward Contract Hedging Tahun 2015

\begin{tabular}{|c|c|c|c|c|c|c|c|c|c|c|}
\hline No & $\begin{array}{l}\text { Tanggal } \\
\text { Transaksi }\end{array}$ & $\begin{array}{l}\text { Kurs } \\
\text { Spot } \\
(\text { Rp) }\end{array}$ & $\begin{array}{l}\text { Nilai } \\
\text { Transaksi } \\
\text { (USD) }\end{array}$ & $\begin{array}{c}\text { Bunga } \\
\text { Deposito } \\
\text { Per } \\
\text { Tahun } \\
(\%) \\
\text { USD }\end{array}$ & $\begin{array}{c}\text { Bunga } \\
\text { Deposi } \\
\text { to Per } \\
\text { Tahun } \\
(\%) \\
\text { Rp }\end{array}$ & $\begin{array}{c}\text { Selisih } \\
(\%)\end{array}$ & $\begin{array}{c}\text { Jatuh } \\
\text { Tempo } \\
\text { Forward } \\
\text { Contract } \\
\text { (Hari) }\end{array}$ & $\begin{array}{c}\text { Forward } \\
\text { Premium } \\
(\%)\end{array}$ & $\begin{array}{c}\text { Kurs } \\
\text { Forward } \\
\text { (Rp) }\end{array}$ & $\begin{array}{c}\text { Jumlah Piutang } \\
\text { Usaha (Rp) }\end{array}$ \\
\hline 1 & $05-01-15$ & 12652 & 5722.08 & 1.23 & 7.89 & 6.66 & 30 & 6.66 & 12722.22 & 72797552.61 \\
\hline 2 & $03-02-15$ & 12706 & 4188.61 & 1.23 & 7.89 & 6.66 & 30 & 6.66 & 12776.52 & 53515852.32 \\
\hline 3 & $19-03-15$ & 13073 & 3609.60 & 1.23 & 7.89 & 6.66 & 30 & 6.66 & 13145.56 & 47450195.87 \\
\hline 4 & $26-03-15$ & 13068 & 13364.37 & 1.23 & 7.89 & 6.66 & 30 & 6.66 & 13140.53 & 175614870.17 \\
\hline 5 & $01-04-15$ & 13108 & 9035.34 & 1.23 & 7.89 & 6.66 & 30 & 6.66 & 13180.75 & 119092552.28 \\
\hline 6 & 08-04-15 & 13067 & 273.48 & 1.23 & 7.89 & 6.66 & 30 & 6.66 & 13139.52 & 3593396.44 \\
\hline 7 & 27-04-15 & 12987 & 8045.88 & 1.23 & 7.89 & 6.66 & 30 & 6.66 & 13059.08 & 105071773.29 \\
\hline 8 & $28-04-15$ & 13043 & 4116.00 & 1.23 & 7.89 & 6.66 & 30 & 6.66 & 13115.39 & 53982939.68 \\
\hline 9 & $04-05-15$ & 13086 & 21229.42 & 1.23 & 7.89 & 6.66 & 30 & 6.66 & 13158.63 & 279350025.58 \\
\hline 10 & $11-05-15$ & 13182 & 13493.08 & 1.23 & 7.89 & 6.66 & 30 & 6.66 & 13255.16 & 178852935.64 \\
\hline 11 & $18-05-15$ & 13182 & 7911.34 & 1.23 & 7.89 & 6.66 & 30 & 6.66 & 13255.16 & 104866078.31 \\
\hline 12 & $25-05-15$ & 13252 & 11439.74 & 1.23 & 7.89 & 6.66 & 30 & 6.66 & 13325.55 & 152440811.34 \\
\hline 13 & 03-06-15 & 13262 & 8412.97 & 1.23 & 7.89 & 6.66 & 30 & 6.66 & 13335.60 & 112192037.23 \\
\hline 14 & 08-06-15 & 13427 & 8122.29 & 1.23 & 7.89 & 6.66 & 30 & 6.66 & 13501.52 & 109663259.66 \\
\hline 15 & $15-06-15$ & 13400 & 7605.72 & 1.23 & 7.89 & 6.66 & 30 & 6.66 & 13474.37 & 102482285.40 \\
\hline 16 & $23-06-15$ & 13383 & 8080.00 & 1.23 & 7.89 & 6.66 & 30 & 6.66 & 13457.28 & 108734787.25 \\
\hline 17 & $24-06-15$ & 13346 & 4002.59 & 1.23 & 7.89 & 6.66 & 30 & 6.66 & 13420.07 & 53715039.18 \\
\hline 18 & 29-06-15 & 13423 & 10255.01 & 1.23 & 7.89 & 6.66 & 30 & 6.66 & 13497.50 & 138416973.38 \\
\hline 19 & 03-08-15 & 13559 & 11887.78 & 1.23 & 7.89 & 6.66 & 30 & 6.66 & 13634.25 & 162080993.59 \\
\hline 20 & $11-08-15$ & 13609 & 12261.50 & 1.23 & 7.89 & 6.66 & 30 & 6.66 & 13684.53 & 167792863.98 \\
\hline 21 & $24-08-15$ & 14068 & 12131.57 & 1.23 & 7.89 & 6.66 & 30 & 6.66 & 14146.08 & 171614128.20 \\
\hline 22 & $31-08-15$ & 14097 & 5665.57 & 1.23 & 7.89 & 6.66 & 30 & 6.66 & 14175.24 & 80310805.14 \\
\hline 23 & 07-09-15 & 14305 & 10051.69 & 1.23 & 7.89 & 6.66 & 30 & 6.66 & 14384.39 & 144587456.76 \\
\hline 24 & 22-09-15 & 14558 & 8288.00 & 1.23 & 7.89 & 6.66 & 30 & 6.66 & 14638.80 & 121326348.71 \\
\hline 25 & 28-09-15 & 14769 & 25705.47 & 1.23 & 7.89 & 6.66 & 30 & 6.66 & 14850.97 & 381751111.11 \\
\hline 26 & $12-10-15$ & 13533 & 9369.20 & 1.23 & 7.89 & 6.66 & 30 & 6.66 & 13608.11 & 127497086.88 \\
\hline 27 & $30-10-15$ & 13707 & 3714.75 & 1.23 & 7.89 & 6.66 & 30 & 6.66 & 13783.07 & 51200673.58 \\
\hline 28 & $09-11-15$ & 13755 & 18428.91 & 1.23 & 7.89 & 6.66 & 30 & 6.66 & 13831.34 & 254896524.65 \\
\hline 29 & $16-11-15$ & 13801 & 14112.56 & 1.23 & 7.89 & 6.66 & 30 & 6.66 & 13877.60 & 195848399.86 \\
\hline 30 & $17-11-15$ & 13780 & 11659.93 & 1.23 & 7.89 & 6.66 & 30 & 6.66 & 13856.48 & 161565575.19 \\
\hline 31 & $01-12-15$ & 13877 & 9587.44 & 1.23 & 7.89 & 6.66 & 30 & 6.66 & 13954.02 & 133783304.10 \\
\hline 32 & $15-12-15$ & 14135 & 20311.34 & 1.23 & 7.89 & 6.66 & 30 & 6.66 & 14213.45 & 288694200.29 \\
\hline 33 & $28-12-15$ & 13707 & 6382.04 & 1.23 & 7.89 & 6.66 & 30 & 6.66 & 13783.07 & 87964128.63 \\
\hline 34 & $29-12-15$ & 13726 & 4750.07 & 1.23 & 7.89 & 6.66 & 30 & 6.66 & 13802.18 & 65561317.83 \\
\hline \multicolumn{10}{|c|}{ Jumlah } & $4,568,308,284.11$ \\
\hline
\end{tabular}


Tabel 3.

Tabel Analisis Teknik Forward Contract Hedging Tahun 2016

\begin{tabular}{|c|c|c|c|c|c|c|c|c|c|c|}
\hline No & $\begin{array}{c}\text { Tanggal } \\
\text { Transaksi }\end{array}$ & $\begin{array}{l}\text { Kurs } \\
\text { Spot } \\
\text { (Rp) }\end{array}$ & $\begin{array}{c}\text { Nilai } \\
\text { Transaksi } \\
\text { (USD) }\end{array}$ & $\begin{array}{c}\text { Bunga } \\
\text { Deposi } \\
\text { to Per } \\
\text { Tahun } \\
(\%) \\
\text { USD }\end{array}$ & $\begin{array}{c}\text { Bunga } \\
\text { Deposi } \\
\text { to Per } \\
\text { Tahun } \\
(\%) \\
\text { Rp } \\
\end{array}$ & $\begin{array}{c}\text { Selisih } \\
(\%)\end{array}$ & $\begin{array}{c}\text { Jatuh } \\
\text { Tempo } \\
\text { Forward } \\
\text { Contract } \\
\text { (Hari) }\end{array}$ & $\begin{array}{c}\text { Forward } \\
\text { Premium } \\
\quad(\%)\end{array}$ & $\begin{array}{c}\text { Kurs } \\
\text { Forward } \\
\text { (Rp) }\end{array}$ & $\begin{array}{c}\text { Jumlah Piutang } \\
\text { Usaha (Rp) }\end{array}$ \\
\hline 1 & 04-01-16 & 13967 & 9210.12 & 1.05 & 7 & 5.95 & 30 & 5.95 & 14036.25 & 129275574.86 \\
\hline 2 & $07-01-16$ & 14016 & 3443.06 & 1.05 & 7 & 5.95 & 30 & 5.95 & 14085.50 & 48497207.86 \\
\hline 3 & $11-01-16$ & 14005 & 6829.70 & 1.05 & 7 & 5.95 & 30 & 5.95 & 14074.44 & 96124212.83 \\
\hline 4 & $18-01-16$ & 14001 & 5973.86 & 1.05 & 7 & 5.95 & 30 & 5.95 & 14070.42 & 84054728.93 \\
\hline 5 & $19-01-16$ & 13991 & 4247.00 & 1.05 & 7 & 5.95 & 30 & 5.95 & 14060.37 & 59714400.06 \\
\hline 6 & $09-02-16$ & 13757 & 2594.33 & 1.05 & 7 & 5.95 & 30 & 5.95 & 13825.21 & 35867161.71 \\
\hline 7 & $15-02-16$ & 13543 & 11417.12 & 1.05 & 7 & 5.95 & 30 & 5.95 & 13610.15 & 155388723.86 \\
\hline 8 & $22-02-16$ & 13527 & 7635.49 & 1.05 & 7 & 5.95 & 30 & 5.95 & 13594.07 & 103797396.04 \\
\hline 9 & $13-04-16$ & 13161 & 3458.24 & 1.05 & 7 & 5.95 & 30 & 5.95 & 13226.26 & 45739569.71 \\
\hline 10 & $04-05-16$ & 13312 & 5426.94 & 1.05 & 7 & 5.95 & 30 & 5.95 & 13378.01 & 72601632.26 \\
\hline 11 & $10-05-16$ & 13400 & 19039.16 & 1.05 & 7 & 5.95 & 30 & 5.95 & 13466.44 & 256389737.52 \\
\hline 12 & $11-05-16$ & 13337 & 4629.55 & 1.05 & 7 & 5.95 & 30 & 5.95 & 13403.13 & 62050457.21 \\
\hline 13 & $23-05-16$ & 13675 & 7268.45 & 1.05 & 7 & 5.95 & 30 & 5.95 & 13742.81 & 99888892.52 \\
\hline 14 & $24-05-16$ & 13674 & 7267.20 & 1.05 & 7 & 5.95 & 30 & 5.95 & 13741.80 & 99864410.78 \\
\hline 15 & $25-05-16$ & 13739 & 9268.49 & 1.05 & 7 & 5.95 & 30 & 5.95 & 13807.12 & 127971177.21 \\
\hline 16 & $30-05-16$ & 13709 & 2507.29 & 1.05 & 7 & 5.95 & 30 & 5.95 & 13776.97 & 34542868.62 \\
\hline 17 & 02-06-16 & 13763 & 2951.41 & 1.05 & 7 & 5.95 & 30 & 5.95 & 13831.24 & 40821664.60 \\
\hline 18 & 06-06-16 & 13545 & 11462.54 & 1.05 & 7 & 5.95 & 30 & 5.95 & 13612.16 & 156029935.65 \\
\hline 19 & 08-06-16 & 13307 & 18780.69 & 1.05 & 7 & 5.95 & 30 & 5.95 & 13372.98 & 251153801.93 \\
\hline 20 & $13-06-16$ & 13408 & 7076.61 & 1.05 & 7 & 5.95 & 30 & 5.95 & 13474.48 & 95353649.35 \\
\hline 21 & $21-06-16$ & 13352 & 21772.80 & 1.05 & 7 & 5.95 & 30 & 5.95 & 13418.20 & 292151864.79 \\
\hline 22 & $27-06-16$ & 13562 & 12125.60 & 1.05 & 7 & 5.95 & 30 & 5.95 & 13629.24 & 165262772.16 \\
\hline 23 & $18-07-16$ & 13178 & 8707.51 & 1.05 & 7 & 5.95 & 30 & 5.95 & 13243.34 & 115316523.47 \\
\hline 24 & $15-08-16$ & 13187 & 9320.40 & 1.05 & 7 & 5.95 & 30 & 5.95 & 13252.39 & 123517534.20 \\
\hline 25 & $16-08-16$ & 13163 & 8227.60 & 1.05 & 7 & 5.95 & 30 & 5.95 & 13228.27 & 108836885.80 \\
\hline 26 & $14-09-16$ & 13294 & 10337.50 & 1.05 & 7 & 5.95 & 30 & 5.95 & 13359.92 & 138108132.51 \\
\hline 27 & $21-09-16$ & 13214 & 13965.91 & 1.05 & 7 & 5.95 & 30 & 5.95 & 13279.52 & 185460573.02 \\
\hline 28 & 04-10-16 & 13053 & 8891.60 & 1.05 & 7 & 5.95 & 30 & 5.95 & 13117.72 & 116637529.16 \\
\hline 29 & $06-10-16$ & 13057 & 10102.08 & 1.05 & 7 & 5.95 & 30 & 5.95 & 13121.74 & 132556876.90 \\
\hline 30 & $12-10-16$ & 13088 & 14283.16 & 1.05 & 7 & 5.95 & 30 & 5.95 & 13152.89 & 187864898.99 \\
\hline 31 & $18-10-16$ & 13109 & 14937.14 & 1.05 & 7 & 5.95 & 30 & 5.95 & 13174.00 & 196781864.31 \\
\hline 32 & $25-10-16$ & 13087 & 10608.15 & 1.05 & 7 & 5.95 & 30 & 5.95 & 13151.89 & 139517218.81 \\
\hline 33 & $08-11-16$ & 13155 & 6800.40 & 1.05 & 7 & 5.95 & 30 & 5.95 & 13220.23 & 89902830.84 \\
\hline 34 & $15-11-16$ & 13405 & 10922.26 & 1.05 & 7 & 5.95 & 30 & 5.95 & 13471.47 & 147138859.24 \\
\hline 35 & $28-11-16$ & 13534 & 5985.55 & 1.05 & 7 & 5.95 & 30 & 5.95 & 13601.11 & 81410100.52 \\
\hline 36 & $07-12-16$ & 13403 & 11189.64 & 1.05 & 7 & 5.95 & 30 & 5.95 & 13469.46 & 150718369.70 \\
\hline \multicolumn{10}{|c|}{ Jumlah } & $4,426,310,037.10$ \\
\hline
\end{tabular}


Gita Syeba Lubis, Analisis Penggunaan Forward Contract dan Option...

Teknik option hedging dilakukan oleh perusahaan dengan put option (opsi jual) pada pasar opsi dengan menentukan kesepakatan strike price dan biaya premi yang kemudian ditetapkan pada kontrak. Perusahaan tidak pernah menerapkan teknik hedging option sehingga diasumsikan perhitungan option menggunakan asumsi pada penelitian sebelumnya oleh Maurer dan Valiani (2007). Asumsi tersebut menetapkan bahwa option akan in-the-money senilai lima persen lebih besar dari kurs spot tiap awal bulan, at-the-money senilai sama dengan kurs spot tiap awal bulan, dan out-themoney senilai satu persen lebih kecil dari kurs spot tiap awal bulan.

Berdasarkan tujuan dari penggunaan teknik hedging yaitu untuk meminimalisasi risiko exchange rate, maka diasumsikan bahwa penggunaan option hedging akan mengalami in-the-money saat dieksekusi sehingga strike price dapat diasumsikan senilai lima persen lebih besar dari kurs spot tiap awal bulan. Berikut merupakan tabel hasil analisis jumlah penerimaan piutang dengan menggunakan teknik option hedging. 
Tabel 4.

Tabel Analisis dengan Teknik Option Hedging Tahun 2014

\begin{tabular}{|c|c|c|c|c|c|c|}
\hline No & $\begin{array}{l}\text { Tanggal } \\
\text { Transaksi }\end{array}$ & $\begin{array}{l}\text { Kurs } \\
\text { Spot } \\
(\text { Rp) }\end{array}$ & $\begin{array}{c}\text { Nilai } \\
\text { Transaksi } \\
\text { (USD) }\end{array}$ & $\begin{array}{l}\text { Strike } \\
\text { Price } \\
\text { (Rp) }\end{array}$ & Premi & $\begin{array}{c}\text { Jumlah Piutang } \\
\text { Usaha (Rp) }\end{array}$ \\
\hline 1 & 03-01-14 & 12287 & 8625.24 & 12902.15 & 615.15 & 111284140.27 \\
\hline 2 & $13-01-14$ & 12107 & 6546.70 & 12722.15 & 615.15 & 83288099.41 \\
\hline 3 & $27-01-14$ & 12259 & 2199.15 & 12874.15 & 615.15 & 28312186.97 \\
\hline 4 & 02-04-14 & 11360 & 5645.98 & 11926.35 & 566.35 & 67335933.57 \\
\hline 5 & 08-04-14 & 11366 & 5909.90 & 11932.35 & 566.35 & 70518995.27 \\
\hline 6 & 14-04-14 & 11501 & 4369.12 & 12067.35 & 566.35 & 52723700.23 \\
\hline 7 & $25-04-14$ & 11659 & 6605.39 & 12251.85 & 592.85 & 80928247.47 \\
\hline 8 & $06-05-14$ & 11569 & 4591.05 & 12148.75 & 579.75 & 55775518.69 \\
\hline 9 & 02-06-14 & 11799 & 4172.04 & 12388.95 & 589.95 & 51687194.96 \\
\hline 10 & $18-06-14$ & 12038 & 3695.56 & 12627.95 & 589.95 & 46667346.90 \\
\hline 11 & $10-07-14$ & 11607 & 4875.78 & 12199.85 & 592.85 & 59483784.63 \\
\hline 12 & 02-09-14 & 11793 & 4467.00 & 12381.45 & 588.45 & 55307937.15 \\
\hline 13 & 24-09-14 & 12036 & 4357.27 & 12624.45 & 588.45 & 55008137.25 \\
\hline 14 & $03-10-14$ & 12205 & 7420.60 & 12817.45 & 612.45 & 95113169.47 \\
\hline 15 & $16-10-14$ & 12268 & 3052.41 & 12880.45 & 612.45 & 39316414.38 \\
\hline 16 & $29-10-14$ & 12224 & 5919.05 & 12836.45 & 612.45 & 75979589.37 \\
\hline 17 & 03-11-14 & 12166 & 5279.68 & 12774.30 & 608.30 & 67444216.22 \\
\hline 18 & $13-11-14$ & 12252 & 3150.41 & 12860.30 & 608.30 & 40515217.72 \\
\hline 19 & $17-11-14$ & 12254 & 5969.94 & 12862.30 & 608.30 & 76787159.26 \\
\hline 20 & $09-12-14$ & 12409 & 4304.86 & 13025.25 & 616.25 & 56071877.72 \\
\hline 21 & $10-12-14$ & 12398 & 6697.93 & 13014.25 & 616.25 & 87168535.50 \\
\hline 22 & $12-12-14$ & 12494 & 1868.75 & 13110.25 & 616.25 & 24499779.69 \\
\hline \multicolumn{6}{|c|}{ Jumlah } & $1,381,217,182.11$ \\
\hline
\end{tabular}


Tabel 5.

Tabel Analisis dengan Teknik Option Hedging Tahun 2015

\begin{tabular}{|c|c|c|c|c|c|c|}
\hline No & $\begin{array}{c}\text { Tanggal } \\
\text { Transaksi }\end{array}$ & $\begin{array}{l}\text { Kurs } \\
\text { Spot } \\
\text { (Rp) }\end{array}$ & $\begin{array}{c}\text { Nilai } \\
\text { Transaksi } \\
\text { (USD) }\end{array}$ & $\begin{array}{l}\text { Strike } \\
\text { Price } \\
\text { (Rp) }\end{array}$ & Premi & $\begin{array}{c}\text { Jumlah Piutang } \\
\text { Usaha (Rp) }\end{array}$ \\
\hline 1 & $05-01-15$ & 12652 & 5722.08 & 13278.80 & 626.80 & 75982355.90 \\
\hline 2 & 03-02-15 & 12706 & 4188.61 & 13344.20 & 638.20 & 55893649.56 \\
\hline 3 & $19-03-15$ & 13073 & 3609.60 & 13725.90 & 652.90 & 49545008.64 \\
\hline 4 & $26-03-15$ & 13068 & 13364.37 & 13720.90 & 652.90 & 183371184.33 \\
\hline 5 & 01-04-15 & 13108 & 9035.34 & 13763.40 & 655.40 & 124356998.56 \\
\hline 6 & 08-04-15 & 13067 & 273.48 & 13722.40 & 655.40 & 3752801.95 \\
\hline 7 & $27-04-15$ & 12987 & 8045.88 & 13642.40 & 655.40 & 109765113.31 \\
\hline 8 & $28-04-15$ & 13043 & 4116.00 & 13698.40 & 655.40 & 56382614.40 \\
\hline 9 & $04-05-15$ & 13086 & 21229.42 & 13740.30 & 654.30 & 291698599.63 \\
\hline 10 & $11-05-15$ & 13182 & 13493.08 & 13836.30 & 654.30 & 186694302.80 \\
\hline 11 & $18-05-15$ & 13182 & 7911.34 & 13836.30 & 654.30 & 109463673.64 \\
\hline 12 & $25-05-15$ & 13252 & 11439.74 & 13906.30 & 654.30 & 159084456.36 \\
\hline 13 & 03-06-15 & 13262 & 8412.97 & 13926.80 & 664.80 & 117165750.60 \\
\hline 14 & $08-06-15$ & 13427 & 8122.29 & 14091.80 & 664.80 & 114457686.22 \\
\hline 15 & $15-06-15$ & 13400 & 7605.72 & 14064.80 & 664.80 & 106972930.66 \\
\hline 16 & $23-06-15$ & 13383 & 8080.00 & 14047.80 & 664.80 & 113506224.00 \\
\hline 17 & $24-06-15$ & 13346 & 4002.59 & 14010.80 & 664.80 & 56079487.97 \\
\hline 18 & $29-06-15$ & 13423 & 10255.01 & 14087.80 & 664.80 & 144470529.88 \\
\hline 19 & $03-08-15$ & 13559 & 11887.78 & 14236.95 & 677.95 & 169245729.47 \\
\hline 20 & $11-08-15$ & 13609 & 12261.50 & 14286.95 & 677.95 & 175179437.43 \\
\hline 21 & $24-08-15$ & 14068 & 12131.57 & 14745.95 & 677.95 & 178891524.64 \\
\hline 22 & $31-08-15$ & 14097 & 5665.57 & 14774.95 & 677.95 & 83708513.47 \\
\hline 23 & 07-09-15 & 14305 & 10051.69 & 15012.55 & 707.55 & 150901498.71 \\
\hline 24 & $22-09-15$ & 14558 & 8288.00 & 15265.55 & 707.55 & 126520878.40 \\
\hline 25 & $28-09-15$ & 14769 & 25705.47 & 15476.55 & 707.55 & 397831991.73 \\
\hline 26 & $12-10-15$ & 13533 & 9369.20 & 14269.35 & 736.35 & 133692394.02 \\
\hline 27 & $30-10-15$ & 13707 & 3714.75 & 14443.35 & 736.35 & 53653434.41 \\
\hline 28 & $09-11-15$ & 13755 & 18428.91 & 14442.50 & 687.50 & 266159532.68 \\
\hline 29 & $16-11-15$ & 13801 & 14112.56 & 14488.50 & 687.50 & 204469825.56 \\
\hline 30 & $17-11-15$ & 13780 & 11659.93 & 14467.50 & 687.50 & 168690037.28 \\
\hline 31 & $01-12-15$ & 13877 & 9587.44 & 14570.85 & 693.85 & 139697150.12 \\
\hline 32 & $15-12-15$ & 14135 & 20311.34 & 14828.85 & 693.85 & 301193814.16 \\
\hline 33 & $28-12-15$ & 13707 & 6382.04 & 14400.85 & 693.85 & 91906800.73 \\
\hline 34 & $29-12-15$ & 13726 & 4750.07 & 14419.85 & 693.85 & 68495296.89 \\
\hline \multicolumn{6}{|c|}{ Jumlah } & $4,768,881,228.11$ \\
\hline
\end{tabular}


Tabel 6.

Tabel Analisis dengan Teknik Option Hedging Tahun 2016

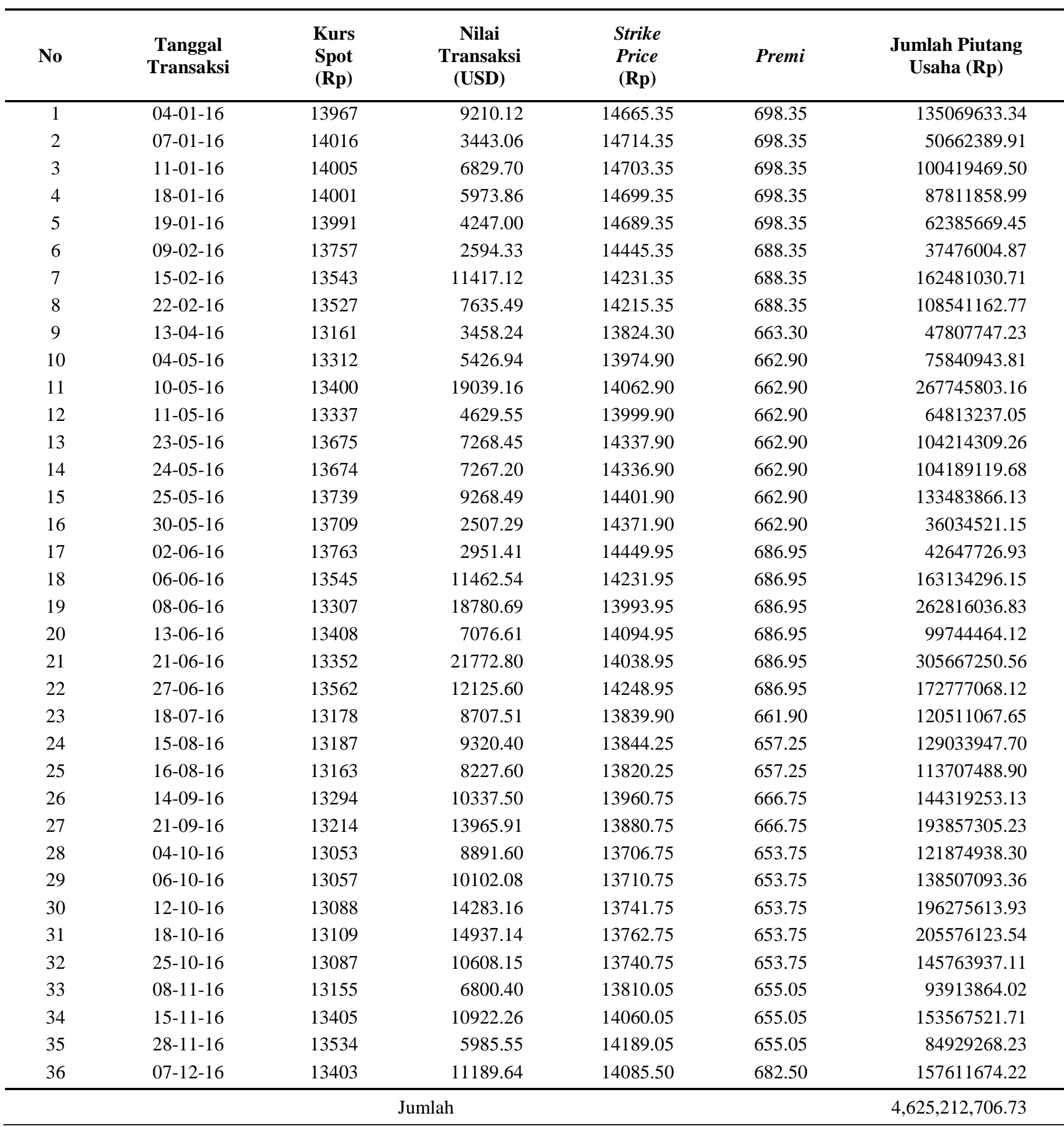


Gita Syeba Lubis, Analisis Penggunaan Forward Contract dan Option...

Analisis data yang dilakukan pada penelitian ini menunjukkan sebuah hasil dari penerapan teknik hedging forward contract dan option. Usaha ini dilakukan untuk melindungi mata uang dari risiko exchange rate.

Berdasarkan analisis data diperoleh hasil yaitu penerapan forward contract hedging mampu melindungi nilai mata uang dari risiko exchange rate dengan menghasilkan peningkatan selisih kurs dibandingkan tidak menggunakan teknik hedging forward contract.

Tabel 7.

Tabel Penerimaan Piutang dengan Forward Contract

\begin{tabular}{cccc}
\hline Tahun & $\begin{array}{c}\text { Tanpa Hedging } \\
(\mathbf{R p})\end{array}$ & $\begin{array}{c}\text { Forward Contract } \\
(\mathbf{R p})\end{array}$ & Selisih $(\mathbf{R p )})$ \\
\hline 2014 & $1,315,478,885.25$ & $1,322,823,642.36$ & $7,344,757.11$ \\
2015 & $4,543,094,111.79$ & $4,568,308,284.11$ & $25,214,172.32$ \\
2016 & $4,404,471,201.53$ & $4,426,310,037.10$ & $21,838,835.57$ \\
\hline Jumlah & $10,263,044,198.57$ & $10,317,441,963.57$ & $54,397,765.00$ \\
\hline
\end{tabular}

Sumber: Data diolah, 2017

Selama Tahun 2014-2016 UD Damena beroperasi tanpa melakukan perlindungan nilai terhadap penerimaan piutangnya dalam mata uang $U S$ Dollar. Hal ini berdampak pada jumlah Rupiah yang diterima perusahaan ketika penerimaan piutang dalam US Dollar dikonversikan ke dalam Rupiah karena UD Damena akan menghadapi risiko exchange rate. Risiko ini menyebabkan adanya fluktuasi nilai Rupiah terhadap US Dollar yang dapat membuat nilai Rupiah melemah atau menguat terhadap US Dollar tanpa bisa diprediksi dengan tepat. Untuk meminimalisasi adanya risiko exchange 
rate, UD Damena dapat melakukan teknik hedging terhadap penerimaan piutangnya, salah satunya dengan menggunakan teknik forward contract.

Tabel 7 menunjukkan hasil penerimaan piutang UD Damena pada Tahun 2014-2016 saat tidak melakukan hedging dan saat diasumsikan melakukan forward contract hedging. Penerimaan piutang UD Damena saat tidak melalukan hedging adalah sebesar Rp10,263,044,198.57 sedangkan saat diasumsikan melakukan forward contract hedging penerimaan piutang meningkat menjadi sebesar Rp10,317,441,963.57 atau terdapat peningkatan selisih kurs yaitu sebesar Rp54,397,765.00. Hasil tersebut menyimpulkan bahwa penerapan forward contract hedging mampu meminimalisasi risiko exchange rate karena jumlah penerimaan piutang saat diasumsikan melakukan forward contract hedging lebih besar daripada saat tidak melakukan hedging. Hal ini disebabkan karena forward rate bernilai lebih besar daripada kurs spot sehingga jumlah Rupiah yang diterima UD Damena lebih banyak saat melakukan forward contract hedging. Hasil penelitian ini mendukung teori hedging yang mendasari penelitian ini yaitu mengenai fungsi penerapan teknik hedging untuk meminimalisasi risiko exchange rate serta mendukung hasil penelitian terdahulu yang telah dilakukan oleh Rofifah dkk. (2017) dan Alim (2014) yang menemukan hasil serupa bahwa forward contract hedging mampu melindungi perusahaan dari risiko exchange rate dan menghasilkan peningkatan selisih kurs.

Berdasarkan analisis data diperoleh hasil yaitu penerapan option hedging mampu melindungi nilai mata uang dari risiko exchange rate 
Gita Syeba Lubis, Analisis Penggunaan Forward Contract dan Option...

dengan menghasilkan peningkatan selisih kurs dibandingkan tidak menggunakan teknik hedging option.

Tabel 8.

Tabel Penerimaan Piutang dengan Option

\begin{tabular}{cccc}
\hline Tahun & $\begin{array}{c}\text { Tanpa Hedging } \\
(\mathbf{R p})\end{array}$ & $\begin{array}{c}\text { Option } \\
(\mathbf{R p})\end{array}$ & Selisih (Rp) \\
\hline 2014 & $1,315,478,885.25$ & $1,381,217,182.11$ & $65,738,296.86$ \\
2015 & $4,543,094,111.79$ & $4,768,881,228.11$ & $225,787,116.32$ \\
2016 & $4,404,471,201.53$ & $4,625,212,706.73$ & $220,741,505.20$ \\
\hline Jumlah & $10,263,044,198.57$ & $10,775,311,116.95$ & $512,266,918.38$ \\
\hline
\end{tabular}

Tabel 8 menunjukkan hasil penerimaan piutang UD Damena pada Tahun 2014-2016 saat tidak melakukan hedging dan saat diasumsikan melakukan option hedging. Penerimaan piutang UD Damena saat tidak melakukan hedging adalah sebesar Rp10,263,044,198.57 sedangkan saat diasumsikan melakukan option hedging penerimaan piutang meningkat menjadi sebesar Rp10,775,311,116.95 atau terdapat peningkatan selisih kurs yaitu sebesar Rp512,266,918.38. Hasil tersebut menyimpulkan bahwa penerapan option hedging mampu meminimalisasi risiko exchange rate karena hasil penerimaan piutang saat diasumsikan melakukan option hedging lebih besar daripada saat tidak melakukan hedging. Hal ini disebabkan karena strike price bernilai lebih besar daripada kurs spot sehingga jumlah Rupiah yang diterima UD Damena lebih banyak saat melakukan option hedging. Hasil penelitian ini mendukung teori hedging yang mendasari penelitian ini yaitu mengenai fungsi penerapan teknik 
hedging untuk meminimalisasi risiko exchange rate serta mendukung hasil penelitian terdahulu yang telah dilakukan oleh Maurer dan Valiani (2007), Chan et al. (2003), dan Khazeh dan Winder (2006) yang menunjukkan hasil bahwa option hedging mampu melindungi perusahaan dari risiko exchange rate dan menghasilkan peningkatan selisih kurs.

Berdasarkan analisis data diperoleh hasil yaitu penerapan teknik forward contract dan option hedging mampu meminimalisasi risiko exchange rate pada perusahaan UD Damena Tahun 2014-2016. Namun, teknik hedging option menghasilkan penerimaan piutang yang lebih besar dibandingkan dengan forward contract.

Tabel 9.

Tabel Penerimaan Piutang Forward Contract dan Option

\begin{tabular}{cccc}
\hline Tahun & $\begin{array}{c}\text { Forward Contract } \\
(\mathbf{R p})\end{array}$ & $\begin{array}{c}\text { Option } \\
(\mathbf{R p})\end{array}$ & Selisih (Rp) \\
\hline 2014 & $1,322,823,642.36$ & $1,381,217,182.11$ & $58,393,539.75$ \\
2015 & $4,568,308,284.11$ & $4,768,881,228.11$ & $200,572,944.00$ \\
2016 & $4,426,310,037.10$ & $4,625,212,706.73$ & $198,902,669.63$ \\
\hline Jumlah & $10,317,441,963.57$ & $10,775,311,116.95$ & $457,869,153.38$ \\
\hline Sumber: Data diolah, 2017 & &
\end{tabular}

Tabel 9 menunjukkan jumlah penerimaan piutang UD Damena pada Tahun 2014-2016 dengan asumsi menggunakan forward contract dan option. Dengan asumsi menggunakan teknik option jumlah penerimaan piutang UD Damena adalah sebesar Rp10,775,311,116.95 sedangkan dengan asumsi menggunakan teknik forward contract jumlah penerimaan piutang UD Damena adalah sebesar Rp10,317,441,963.57 atau terdapat 
Gita Syeba Lubis, Analisis Penggunaan Forward Contract dan Option...

peningkatan selisih kurs sebesar Rp457,869,153.38. Berdasarkan hasil tersebut maka dapat disimpulkan bahwa penerapan option lebih menguntungkan daripada forward contract karena jumlah penerimaan piutangnya lebih banyak dan hal tersebut menunjukkan bahwa peningkatan selisih kursnya lebih besar. Peningkatan selisih kurs yang diterima oleh UD Damena dengan menerapkan option akan menutupi biaya premi yang harus dibayar saat awal perjanjian option serta memberikan keuntungan yang lebih besar terhadap penerimaan piutang saat option di eksekusi.

\section{SIMPULAN}

Berdasakan hasil analisis data dan pembahasan yang telah diuraikan sebelumnya, maka dapat ditarik kesimpulan bahwa penerapan hedging dengan menggunakan forward contract dan option mampu meminimalisasi risiko exchange rate pada perusahaan UD Damena pada Tahun 2014-2016. Hasil penelitian menunjukkan bahwa penerimaan piutang dengan menggunakan teknik hedging forward contract dan option lebih banyak daripada tidak menggunakan hedging. Hasil penelitian juga menemukan bahwa penerapan option lebih baik digunakan daripada forward contract dalam meminimalisasi risiko exchange rate pada perusahaan UD Damena Tahun 2014-2016. Hasil penelitian menunjukkan bahwa penerimaan piutang dengan menggunakan teknik option lebih banyak daripada forward contract. 


\section{SARAN}

Berdasarkan penelitian ini maka disarankan bagi perusahaan ekspor untuk dapat menerapkan hedging khususnya dengan teknik forward contract dan option guna meminimalisasi risiko exchange rate. Penggunaan forward contract dan option juga disarankan agar dapat melindungi nilai tukar mata uang dari keadaan ekonomi dan politik yang tidak stabil sehingga transaksi perdagangan internasional yang dilakukan perusahaan tidak terkena dampak dari fluktuasi mata uang yang tidak dapat diprediksi. Saran bagi peneliti selanjutnya agar dapat menentukan asumsi nilai strike price sesuai dengan keadaan ekonomi dan politik yang terjadi sehingga asumsi akan lebih akurat. Peneliti juga menyarankan agar penelitian selanjutnya dapat menambahkan dan/atau memilih teknik hedging yang lain seperti swaps, futures, dan money market hedging serta memilih perusahaan yang bergerak di bidang lain pada perdagangan internasional.

\section{REFERENSI}

Afza, Talat and Alam, Atia. 2016. Foreign Currency Derivatives and Firm Value. European Online Journal of Natural and Social Sciences, 5(1):1-14.

Alim, Mochammad, B. 2014. Analisis Forward Contract Hedging Dan Open Position Dalam Menghadapi Eksposur Valuta Asing (Studi Pada PT “XYZ”). Jurnal Mahasiswa Teknologi Pendidikan, 2(2):1-29.

Allayannis, George and Eli Ofek. 1997. Exchange Rate Exposure, Hedging and the Use of Foreign Currency Derivatives, Journal of International Money and Finance, 20(2):273-296.

Anthonius. 2012. Analisa Perbandingan Penggunaan Open Position, Forward Contract, dan Money Market Hedging Terhadap Utang Ekspedisi Luar Negeri (Studi Kasus pada Perusahaan Jasa PT X 
di Bandung). Skripsi Sarjana Jurusan Manajemen pada Fakultas Ekonomi Universitas Kristen Maranatha, Bandung.

Aretz, K., Bartram, S. M and Gunter Dufey. 2008. Why Hedge? Rationales for Coperate Hedging and Value Implication. Journal of Risk Finance, 8(5): 434-449.

Aryanti, Naning Wessiani. 2005. Analisis Eksposur Nilai Tukar Rupiah Terhadap Dollar Amerika pada Industri Manufaktur yang Go Public. Jurnal Bisnis Strategi, 14(1):1-15.

Ball. 2004. International Business: The Challengge of Global Competition $9^{\text {th }} e d$. New York: Mc GrawHill.

Bartram, So"hnke, M. 2008. What Lies Beneath: Foreign Exchange Rate Exposure, Hedging and Cash Flows. Journal of Banking \& Finance, 32(8):1508-1521.

Bodnar, G. M., Jong, A. D. and Macrae, V. 2003. The impact of institutional differences on derivatives usage: a comparative study of US and Dutch firms, European Financial Management, 9:271-97.

Brigham, Eugene, F dan Houston, Joel, F. 2011. Dasar-dasar Manajemen Keuangan, Buku 2 Edisi 11. Jakarta: Salemba Empat.

Broll, Udo., Welzel, Peter., and Pong, K.W. 2009. Export and Strategic Currency Hedging. Springer Science + Business Media, 20:717-732.

Chan, K.F., Gan, Christopher., and McGraw, P.A. 2003. A Hedging Strategy for New Zealand's Exporters in Transaction Exposure to Currency Risk. Multinational Finance Journal, 7(1\&2):25-54.

Clark, Ephraim and Judge, Amrit. 2008. The Determinants of Foreign Currency Hedging: Does Foreign Currency Debt Induce a Bias? European European Financial Management, 14(3):445-469.

Clark, Ephraim and Judge, Amrit. 2009. Foreign Currency Derivatives versus Foreign Currency Debt and the Hedging Premium. European Financial Management, 15(3):606-642.

Daryono, Rino. 2011. Analisis Perbandingan Penggunaan Teknik Hedging Forward Contract Hedge dan Money Market Hedge dengan Open Position dalam Penerimaan Piutang Ekspor PT X. Undergraduate Thesis, Universitas Kristen Maranatha.

Eiteman, David K., Artur I. Stonehill and Michael H.M. 2004. Multinational Business Finance, $10^{\text {th }}$ Edition. Addition-Wesley Publishing Company. USA.

Enggawati, Jevi., Dzulkirom, Moch., dan Hidayat, Raden R. 2013. Analisis Penggunaan Teknik Hedging Contract Forward Untuk Mengurangi 
Kerugian Selisih Kurs Valas Atas Hasil Penjualan Ekspor. Jurnal Universitas Brawijaya, 1(2).

Fahmi, Irham. 2016. Pengantar Manajemen Keuangan Teori dan Soal Jawab. Bandung: Penerbit Alfabeta.

Ghosh, Sanjoy and Marston, Richard. 2000. Hedging Currency Exposure. University of Pennsylvania, ProQuest Dissertations Publishing.

Griffin, Ricky W. dan Michael W. Pustay. 2005. Bisnis Internasional: Perspektif Manajerial Jilid 1. Edisi ke 4. Jakarta: PT Index.

Guay, Wayne and Sophari, S.P. 2003. How much do firms hedge with derivatives? Journal of Financial Economics, 70:423-461.

Guniarti. 2014. Faktor-Faktor Yang Mempengaruhi Aktivitas Hedging Dengan Instrumen Derivatif Valuta Asing. Jurnal Dinamika Manajemen, 5(1): 64-79.

Hady, Hamdy. 2006. Ekonomi Internasional Buku 1. Jakarta: Ghalia Indonesia.

Hady, Hamdy. 2016. Manajemen Keuangan Internasional, Edisi Keempat. Jakarta: Mitra Wacana Media.

Hagelin, N and Pramborg. B. 2004. Hedging Foreign Exchange Exposure: Risk Reduction from Transaction and Translation Hedging. Journal of International Financial Management \& Acounting, 15(1):1-20.

Hanafi, Mamduh. 2009. Manajemen Risiko. Edisi ke 2. Yogyakarta: UPP STIM YKPN.

Haq dan Muniroh. 2015. Analisis Pengelolaan Valuta Asing Terhadap Profitabilitas PT Garuda Indonesia (Persero) Tbk. JIAFE (Jurnal Ilmiah Akuntansi Fakultas Ekonomi), 1(2):77-84.

Horcher, Karen A. 2005. Essentials of Financial Risk Management. New Jersey: John Wiley \& Sons, Inc.

Indriantoro, Nur dan Supomo, Bambang. 2002. Metodologi Penelitian Bisnis, Cetakan Kedua. Yogyakara: Penerbit BFEE UGM.

Khazeh, Kashi and Winder, Robert C. 2006. Hedging Transaction Exposure Through Options and Money Markets: Empirical Findings. Multinational Business Review, 14(1):79-91.

Larasati, Era dan Suarjaya, Gede. 2017. Analisis Forward Contract Hedging dan Open Position dalam Menghadapi Eksposur Valuta Asing. E-Jurnal Manajemen Unud, 6(5):2556-2581.

Levi, Maurice D. 2001. Keuangan Internasional. Edisi Pertama. Yogyakarta: Andi Yogyakarta. 
Gita Syeba Lubis, Analisis Penggunaan Forward Contract dan Option...

Madura, Jeff, 2006, Manajemen Keuangan Internasional, Edisi Keempat (Diterjemahkan oleh Emil Salim). Jakarta: Erlangga.

Madura, Jeff. 2009. Manajemen Keuangan Internasional, Edisi Keempat (Diterjemahkan oleh Emil Salim). Jakarta: Erlangga.

Maurer, Raimond and Valiani, Shohreh. 2007. Hedging the Exchange Rate Risk in International Portfolio Diversification. Managerial Finance, 33(9):667-692.

Moehrle, Jennifer R. 2005. Management's Disclosure of Hedging Activity: An Empirical Investigation of Analysts' and Investors' Reactions. International Journal of Managerial Finance, 1(2):108-122.

Moosa, Imad. A. 2003. Financial and Operational Hedging of Exposure to Foreign Exchange Risk. International Financial Operations, Finance and Capital Markets Series. Palgrave Macmillan, London.

Musthafa. 2017. Manajemen Keuangan, Edisi 1. Yogyakarta: ANDI.

Nurmalasari, M.R dan Purnawati, N.K. 2013. Perbandingan Penggunaan Teknik Hedging Dengan Open Position Dalam Meminimalisasi Nilai Hutang Impor, E-Jurnal Manajemen Universitas Udayana, 2(12):1578-1597.

Pramborg, Bengt. 2005. Foreign Exchange Risk Management by Swedish and Korean Nonfinancial Firm: A Comparative Survey. Pacific-Basin Finance Journal, 13:343-366.

Repie, Renno Reynaldi dan Sedana, Ida Bagus P. 2014. Kebijakan Hedging Dengan Instrumen Derivatif dalam Kaitan Dengan Underinvesment Problem di Indonesia. E-Journal Manajemen Unud, 7(1):384-398.

Rinny dan Saputra, Rishi S. 2016. Analisa Lindung Nilai (Hedging) Terhadap Transaksi Pembelian Bahan Baku Dalam Mata Uang Asing USD (Studi Kasus PT TD Automotive Compressor Indonesia Periode Oktober 2014-Januari 2015. Jurnal Mahasiswa Bina Insani, 1(1):7791.

Rofifah, Tita I., Topowijono dan Nuzula, Nila F. 2017. Penggunaan Contract Forward Hedging Secara Konvensional dan Syariah Dalam Meminimalkan Risiko Nilai Tukar. Jurnal Administrasi Bisnis (JAB), 42: $1-12$.

Saragih, Ferdinand D dan Nugroho, Yuliarto. 2014. Dasar-dasar Keuangan Internasional. Jakarta: PT Raja Grafindo Persada.

Sartono, Agus. 2010, Manajemen Keuangan Teori dan Aplikasi, Edisi 4. Yogyakarta: BPFE-Yogyakarta.

Schmittman, Jochen M. 2010. Currency Hedging for International Portfolios. Paper presented by IMF, Finance Department. 
Schubert, L. 2011. Hedge Ratios for Short and Leveraged Exchange-Trade Funds. Atlantic Review of Economic, 1:11-34.

Sherlita, Erly. 2006. Peranan Aktivitas Lindung Nilai Dalam Menurunkan Risiko Perdagangan Internasional. Jurnal Bisnis, Manajemen \& Ekonomi, 8(2):1227-1238.

Sivakumar, Anuradha and Runa Sarkar. 2007. Corporate Hedging for Foreign Exchange Risk in India. Thesis of Industrial and Management Engineering Department of Indian Institute of Technology, 1-18.

Stice, E.K., K.F Skousen and J.D. Stice. 2004. Intermediate Accounting. Edition 15, Cincinnati: Ohio: South-Western College Publishing.

Sugiyono. 2012. Metode Penelitian Bisnis. Bandung: Alfabeta.

Utomo, Lisa Linawati. 2000. Instrumen Derivatif: Pengenalan Dalam Strategi Manajemen Risiko Keuangan. Jurnal Akuntansi dan Keuangan, 2(1):53-68.

Van Horne, James C. dan M. Jhon Wachowicz, 2005. Prinsip-Prinsip Manajemen Keuangan (Diterjemahkan oleh Aria Farahmita, Amanugrani, dan Taufik Hendrawan), Buku 1 Edisi ke-12. Jakarta: PT Salemba Empat.

Winarto, Jacinta. 2008. Teknik-teknik Hedging yang Dapat Digunakan untuk Menilai Hutang Valuta Asing. Jurnal Ekonomi dan Bisnis, 20(2):164-175.

White, G, I., Ashwinpaul C., Sondhi, and Dov, Fried. 2003. The Analysis and Use of Financial Statement, Third Edition, New York: John Wiley \& Sons Inc.

Wong, K.P., and Yick, H.Y. 2004. Currency Options and Export-Flexible Firms. Bulletin of Economic Research, 56(4):379-394.

Yulianti, Sri Handaru., dan Prasetyo, Handoyo. 2002. Dasar-dasar Manajemen Keuangan Internasional, Edisi Kedua. Yogyakarta: Andi Yogyakarta.

Zeinora. 2015. Analisis Perbandingan Hedging, Swaps Contract dengan Forward Contract Untuk Meminimalisasi Kerugian Selisih Kurs Valas Atas Hasil Penjualan Ekspor. Journal Applied Buisiness and Economics Universitas Indraprasta PGRI, 1(4):296-307.

Zeinora. 2016. Future Contract Dengan Option Contract Untuk Meminimalisasi Resiko Fluktuasi Kurs Valas. SOSIO-E-KONS, 8(1):72-80.

Zhu, M. R. 2010. Corporate Hedging, Financial Distress and Product Market Compettition. Working Paper. Austin: University of Texas. 